\title{
Morpho-anatomical Observations on Homoeopathic Plant Drug Hygrophila spinosa T. Anderson
}

\author{
Digvijay Verma ${ }^{1, *}$, Shilpi Singh ${ }^{1}$, Renu Arya ${ }^{3}$, Soundararajan Rajan ${ }^{2}$, Bhopal Singh Arya $^{1}$, Anil Khurana ${ }^{3}$, \\ Raj Kumar Manchanda ${ }^{3}$
}

\section{Digvijay Verma ${ }^{1 * *}$, Shilpi \\ Singh ${ }^{1}$, Renu Arya ${ }^{3}$, \\ Soundararajan Rajan², Bhopal Singh Arya ${ }^{1}$, Anil Khurana ${ }^{3}$, Raj Kumar Manchanda ${ }^{3}$}

'Pharmacognosy Division, Drug Standardization Unit, Dr. D. P. Rastogi Central Research Institute for Homoeopathy, A-1/1, Sector 24 Noida, Uttar Pradesh-201301, INDIA.

${ }^{2}$ Medicinal Plant Garden Unit, Center for Medicinal Plants Research in Homoeopathy, 3/126 Indira Nagar Emerald, Tamil Nadu-643209, INDIA.

${ }^{3}$ Drug Standardization Unit, Central Council for Research in Homoeopathy, D Block, Janakpuri, New Delhi- 110058, INDIA.

\section{Correspondence}

Mr. Digvijay Verma

Pharmacognosy Division, Drug Standardization Unit, Dr. D. P. Rastogi Central Research Institute for Homoeopathy, A-1/1, Sector 24 Noida Uttar Pradesh-201301, INDIA

Phone no : +91-7398985108

E-mail: digvijayccrh@gmail.com

History

- Submission Date: 27-09-2018;

- Review completed: 22-11-2018;

- Accepted Date: 12-12-2018.

DOI : 10.5530/pj.2019.11.44

Article Available online

http://www.phcogj.com/v11/i2

Copyright

(C) 2019 Phcog.Net. This is an openaccess article distributed under the terms of the Creative Commons Attribution 4.0 International license.

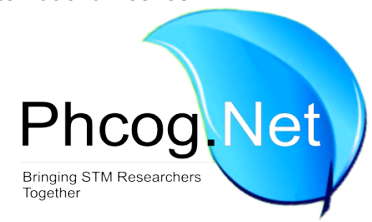

\begin{abstract}
Background: Hygrophila auriculata (Schumach.) Heine synonym Hygrophila spinosa T. Anderson is used in the homoeopathic system of medicine belongs to the family Acanthaceae. Plant contains terpenoids, alkaloids, flavonoids and is traditionally known as an aphrodisiac, renal tonic and for its health-promoting properties, this drug is most popularly used by homoeopathic practitioners for the treatment of urticaria, conjunctivitis, gastroenteritis, nausea etc. Complete morphological characterization of whole plant has not been reported so for. This study may provide complete information on the basis of morphological, anatomical and powdered studies. That will assist to differentiate between adulterants and authentic raw drug to maintain the quality of drugs. Objective: The aim of the present study is to examine the morpho-anatomical, powder and fluorescence analysis of whole plant i.e. root, stem, and leaf of the plant used in homoeopathy. Material and methods: The macroscopical, microscopical and powdered analysis of drug was performed. For morphological study simple observational methods applied while for anatomical and bio-statistical parameters microscopy including powder microscopy was performed by using different methods. Results: The drug was in form of dried pieces of leaves, small quadrangular pieces of stem with spines and roots. Microscopy showed few features like aerenchymatous cortex in the middle region of root; semi-quadrangular outline, four vascular bundles at each corner in young stem and developing fascicular vascular bundles between them, in mature stem 6 vascular bundles viz. 4 vascular bundles at corner and 2 vascular bundles present in between opposite to each other; broad cortical aerenchyma in mature stem, leaf amphistomatous, anomocytic stomata, crescent-shaped meristele in leaf. Conclusion: Present study can assist the diagnostic characters of Hygrophila spinosa may be taken as pharmacognostical standards for the identification of plant drug.
\end{abstract}

Key words: Macroscopy, Microscopy, Organoleptic, Homoeopathy, Drug.

\section{INTRODUCTION}

The homoeopathic plant drug Hygrophila auriculata (Schumach) Heine. known as Hygrophila spinosa T. Anderson (Kule Khara) or Asteracantha longifolia Nees., belongs to family Acanthaceae. ${ }^{1}$ The plant is native to Indian continent, which widely distributed in Sri Lanka, Myanmar, Bangladesh, Nepal, Pakistan, China, Malaysia, Indonesia and South Africa. ${ }^{2-8}$ In India it is reported from moist places or wetland areas on the banks of tanks, paddy fields, ditches and swampy places and often grows mixed with marshy grasses and sedges; distributed throughout plains of India and tropical Himalaya. ${ }^{9}$ It is commonly known as Talmakhana or traditionally while Kokilaksha, Ikshuraka or Vajrakantaka in Ayurveda; where Kokilasha means 'having eyes like Kokila' or the Indian cuckoo; Taalmakhaanaa in Unani (not to be confused with Makhaana or Fox nuts, Euryale ferox Salisb.); and Neermulli in Tamil/ Siddha system of medicine. ${ }^{2,10}$ In German it is called Langblattriger Sterndorn whereas in English it is called Long-leaved barleria. This plant is indigenous to India hence traditionally used as vegetables in many states like Odisha, Bengal and Chattisgarh and used for treatment of many diseases like cancer, urogenital tract, hyperdipsia, diarrhea, dysentery, sexual disorders e.g. leucorrhoea, menorrhagia, blood diseases, painful micturition, urinary disorders, hepatotoxicity, diabetes, constipation, blood disorders and anti-inflammatory in rheumatoid arthritis etc. ${ }^{4,10-11}$ Roots are used for the treatment of diuretics, dropsy, rheumatism, jaundice and killing abdominal insects; leaves are used for the treatment of anaemia; seeds have a potent activity to treat sexual disorders like impotency and gallstones. In Ayurveda sciences whole plant including seeds used for curing the diseases raised from Vata and Pitta doshas while leaves used for increasing bile secretions so help in liver disorders. ${ }^{10}$ In Unani system aksir-ul-imraz is prepared by using seeds as the main constituent along with other is being used for the treatment of leucorrhoea. In Siddha system, it is
Cite this article: Verma D, Singh S, Arya R, Rajan S, Arya BS, Khurana A, et al. Morpho-anatomical Observations on Homoeopathic Plant Drug Hygrophila spinosa T. Anderson. Pharmacog J. 2019;11(2):286-91. 
called Neermulli which is a potent aphrodisiac and used for the treatment of pandu, dropsy, scanty urine, ascites. ${ }^{9}$ In Homoeopathic system mother tincture prepared from whole plant successive potencies $(3 \mathrm{x}, 6 \mathrm{x}, 30 \mathrm{Ch}$.) are being used for curing anasarca and dropsy, gonorrhoea, insomnia, impotency, rheumatism, leucorrhoea, skin disorders, urinary troubles and calculus, hepatic obstruction with dropsy and anasarca etc. ${ }^{1,12}$ This study designed to explore some additional morpho-anatomical characters of Hygrophila spinosa which may serve as a marker to differentiate the authentic and adulterated plant.

\section{Botanical Description}

The plant is an erect armed herb up to 1 meter height, sub quadrangular with the sparsely sub-hispidy hairy stem at each thick node, 6 leaves are arranged in whorls, present at each node having outer 2 leaves are comparatively larger than inner 4 leaves. Leaves are $5-15 \mathrm{~cm}$ long and 1.3 - $2.5 \mathrm{~cm}$ broad, oblong-lanceolate or oblanceolate, sparsely hispid on both surfaces with entire or minutely dentate margin, unicostate venation, sessile or ill-defined petiole. A pair of yellow coloured sharp spines measuring $2.5-4.5 \mathrm{~cm}$ long are present in its axil. ${ }^{7,13}$ Flowering and fruiting may be seen from August to March. ${ }^{4}$ Flowers are arranged in a whorl, axillary, 4 pairs at each node, bracts hairy, lanceolate, up to $2 \mathrm{~cm}$ long; bracteoles linear-lanceolate; calyx silky, 4 - lobed, posterior lobes larger than anterior, 2 toothed; petals violet to purple-blue, united forming up to $1.5 \mathrm{~cm}$ corolla tube, abruptly swollen at the top, sub-equal bi-lipped, $2 / 3$ arrangement; stamens 4 , didynamous, extrose; style slightly pubescent, filiform. ${ }^{14}$ Fruit is a capsule and smaller than calyx; 4 - 8 pointed, linear orbicular and $0.3 \mathrm{~mm}$ long many seeds are present., ${ }^{8,15}$ (Plate $1 \mathrm{~A}-\mathrm{E}$ )

\section{MATERIALS AND METHOD}

\section{Plant collection and identification}

The whole plant including the root of $H$. auriculata was collected from canal side of Thiyagaraja Nagar, Tirunelveli district Tamil Nadu and identified and supplied with accession number 9099. Good collection practices were followed during collection of the plant as per guidelines of National Medicinal Plants Board and Botanical Survey of India. For microscopical study supplied raw drug was first kept in warm water followed by slight warming for $30 \mathrm{~min}$ and then preserved in FAA solution and for macroscopy and powder analysis dried raw drug was used.

Chemicals and reagents: All the chemicals used for the study were of analytical grade and procured from thermo Fischer scientific, Mumbai, India and E. Merk India Limited.

Organoleptic evaluation of drug: To diagnose drug on the basis of their sensory characters like colour, odour, taste etc. comes under organoleptic characterization of the drug. Such parameters were studied to diagnose the organoleptic characters of the drug.

Macroscopic characters: Under this study macroscopic characters of drug-like size, shape and texture of root, stem and leaves were studied; type of leaf and their morphological characters like shape, size, the margin of leaves and presence or absence of petiole and other characters like spines, hairs, glands etc. were observed. ${ }^{16-17}$

Microscopic evaluation: Under the microscopic analysis of drug the qualitative and quantitative analysis was performed. For this analysis trinocular RADICAL RTC S- 7 Microscope was used. ${ }^{16-17}$

Qualitative microscopy: Transverse sections of leaf, stem (young and mature) and root and longitudinal section of the stem was studied under the light microscope. The specimens were dehydrated by using AlcoholTBA- Xylene series followed by embedding in paraffin wax for microtomy. WESWOX MT-1090A microtome was used cutting and sections were cut down ranging between 20 to 40 micrometres. ${ }^{16}$ Sliced sections were heat fixed on the slide using egg albumin and then double staining method
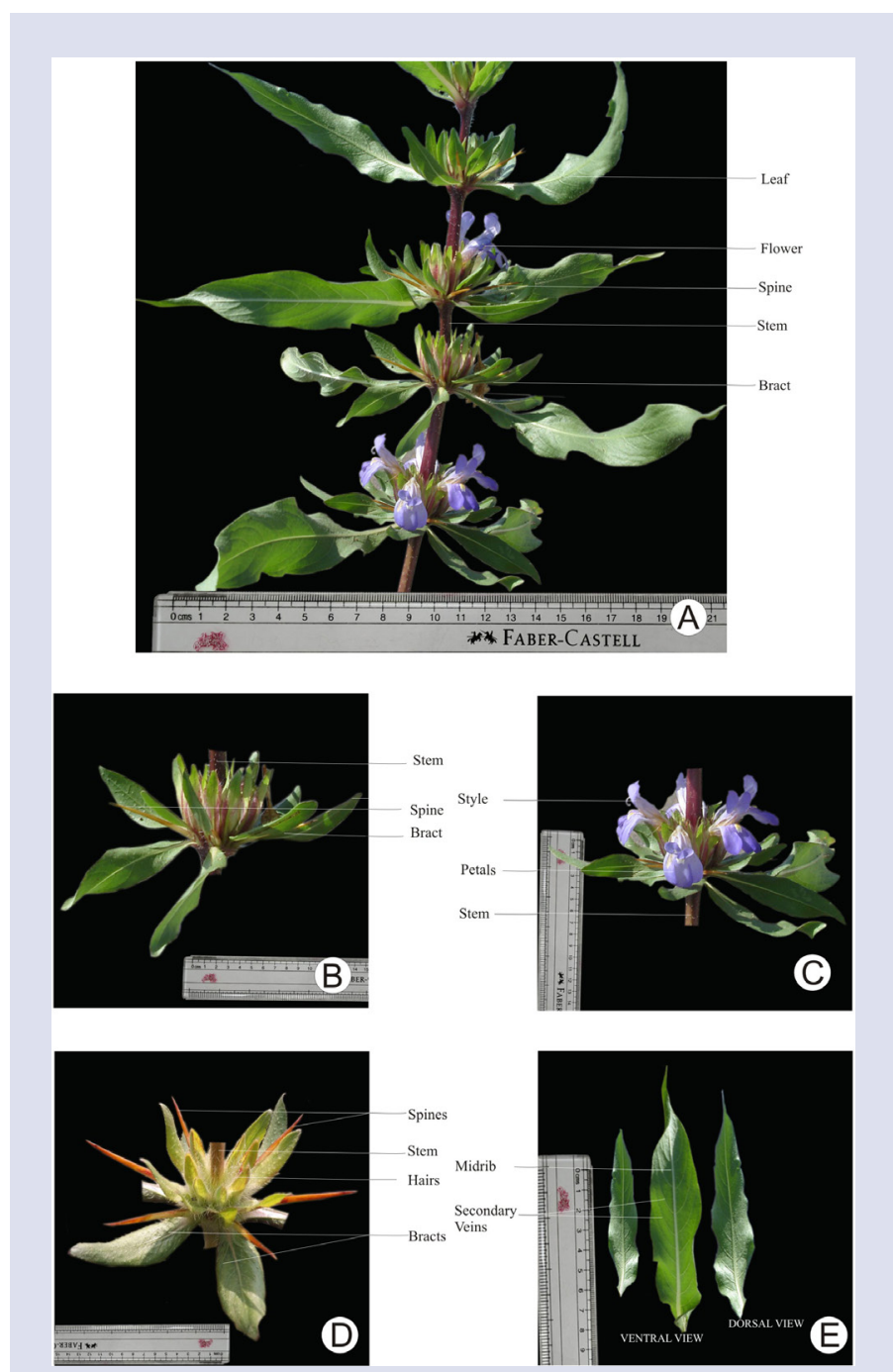

Plate 1: Hygrophila spinosa T. Anderson: A. Habit of the plant; B. Enlarged view of nodal region showing bracts arranged in a whorl; $C$. Englarged view of nodal region showing flowers; D. Enlarged view of nodal region showing 6 spines arrangement in a whorl; E. Dissected leaves showing external morphology along with primary and secondary vein.

was applied as per the method of Johnsons. ${ }^{16}$ Safranin and fast green of Fischer scientific were used as per standard procedures. Different diagnostical characters studied and noted down for identification of drug.

Leaf microscopy: For this study leaves preserved in FAA solution was first washed with running water for about $30 \mathrm{~min}$ and then dipped in saturated chloral hydrate solution for de-colouration. Leaf was mounted in $50 \%$ glycerine solution with and without any reagent for surface study of trichomes, epidermal cells and stomata. Different diagnostical characters were observed, recorded and photomicrography was done.

Stem and root microscopy: The raw drug, boiled and preserved in FAA solution was first washed with running water for 15-20 min followed by dehydration method and embedding protocol for microtomy and staining. For dehydration successive dehydration was done keeping samples of root, stem and leaves in different gradients of Alcohol-Butanol-Xylene series followed by bee wax-paraffin series for preparation of cubes embedded with samples. Microtomy was done by using WESWOX 
microtome and permanent slide prepared as per the method of Johnson. ${ }^{16}$ Stained and without stained sections of plant parts were observed under a microscope. Different layers of cells and their diagnostical characters were recorded followed by photomicrography.

Powder microscopy: Powder microscopy helps to diagnose the presence of identifying characters like the presence of calcium oxalate crystals, starch grains, oil globules, different types of tissues and their components, different types of cells parenchyma, collenchyma or sclerenchyma etc. For this study raw drug was fine grinded with help of mixer grinder and filtered the powder through 40 mesh sieve. The powder was decolourized and kept on the slide and mounted with glycerine and other stains like Iodine (for detection of Starch), safranin (for detection of lignified compounds). The characteristic features of powder under the microscope were observed and noted down and photomicrographs were taken.

Fluorescent analysis: The fluorescent analysis is one of the important parameter for powder drug and presence of various chemical compounds in the plant material where some show fluorescence in visible light while some in U.V. light. In some cases, some chemical compounds change into fluorescent derivatives after treatment with different chemical reagents. ${ }^{4-13}$ We can access qualitatively the diagnostical feature of the drug. For this method, the powder was treated with different chemicals observed in normal visible light and U.V. light and observations were noted down.

Quantitative microscopy: A quantitative microscopy is an important tool for the identification of raw drugs. In this method, leaves were decolourised and peelings were taken with help of forceps and stained with safranin. Peelings were mounted with $50 \%$ glycerine and different leaf characters observed and parameters recorded.

Stomatal index determination: The percentage proportion of the ultimate divisions of the epidermis of leaves which can be converted into stomata is called as a stomatal index. ${ }^{17}$ This can be calculated as the following formula

\section{Stomatal index $=\frac{\text { Stomatal cells }}{\text { Stomatal cells }+ \text { Epidermal cells including Hairs }} \times 100$}

Vein islets and vein termination determination: Vein-islet is the minute area of photosynthetic tissue encircled by ultimate divisions of conducting strands present in per square. ${ }^{17}$ Vein termination is the ultimate free termination of a vein let or branch of vein let in per square mm of leaf surface.$^{17}$ A piece of leaf was de-pigmented by using saturated chloral hydrate solution followed by washing with water. The leaf now stained with safranin and mounted with glycerine for photomicrography. With the help of software $1 \mathrm{~mm}$ square area was drawn and vein islets and vein termination number were counted.

Palisade ratio determination: It is an average number of palisade cells present below the epidermal cells is called palisade ratio. ${ }^{17} \mathrm{~A}$ part of the leaf was first treated with saturated chloral hydrate solution was mounted with $50 \%$ glycerine and focused under the light microscope in such a way so that epidermal cells and palisade cells both are visible simultaneously. The number of palisade cells presents below each epidermal cell was counted (if cells are more than half then included otherwise excluded).

\section{RESULTS}

Macroscopy: Drug occurred as dried pieces of shrivelled brownish leaves, small quadrangular pieces of stem with long sharp spines and small whorled leaves at each node; the group of bracteated flowers, stem branched and quadrangular; odourless and tasteless (Plate $2 \mathrm{~A}$ ).

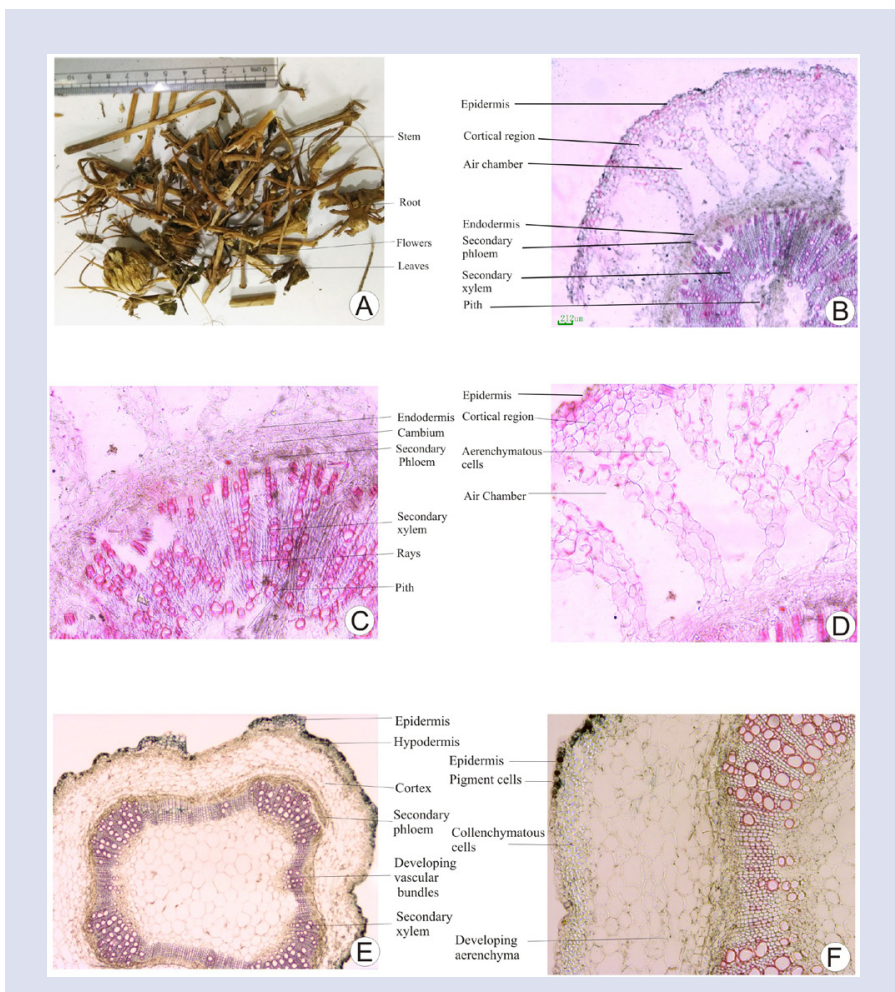

Plate 2: Hygrophila spinosa. A Dried plant drug; B. Transverse section of mature root; $C$. Englarged view of mature root section showing the secondary xylem, secondary phloem, rays and development of cambium; D. Enlarged view of mature root showing the fully developed air chambers; E. Transverse section of young stem showing internal morphology and developmental stage of the vascular bundles; F. Enlarged view of young stem showng developing aerenchyma and xylary elements through furrow region of stem.

Microscopy: Microscopy showed ecologically adaptation to the aquatic environment like presence of broad aerenchyma in roots as well as mature stem.

Root: Transection of root showed circular and slightly wavy outline with a single layer of epidermis. Epidermal cells were somewhat papillose in outer side followed by cortical region that may be divided into distinct three regions viz. outer and inner parenchymatous region, composed of isodiametric, thin-walled parenchymatous cells and broad middle aerenchymatous region consisting oval to elliptical anisodiametric parenchymatous cells forming aerenchymatous strands ranging from bi to multi-seriate stands. Outer cortical cells were 4 - 5 layered, small, elliptical, regular parenchymatous cells while inner cortical cells were 2 - 3 layered and smaller in size. In mature root system endodermis and pericycle not distinguishable and secondary phloem region seen below cortical region. Secondary xylem present along with multiseriate medullary ray's cells forms a continuous ring with outer secondary phloem. Pith region was large and parenchymatous isodiametric, thin-walled parenchymatous cells without intracellular spaces (Plate $2 \mathrm{~B}, \mathrm{C}$ and D).

Stem: Young stem: Transection of stem showed semi-quadrangular outline with less conspicuous single layered, elliptical to oval epidermal cells, some of them were filled with dark brownish pigment. Three to four layered collenchymatous hypodermis was present below epidermis. In young stem cortical region couldn't be differentiated into different zones so cortical region was parenchymatous that showed later on developing aerenchyma; endodermal cells broad, barrel-shaped and prominent 


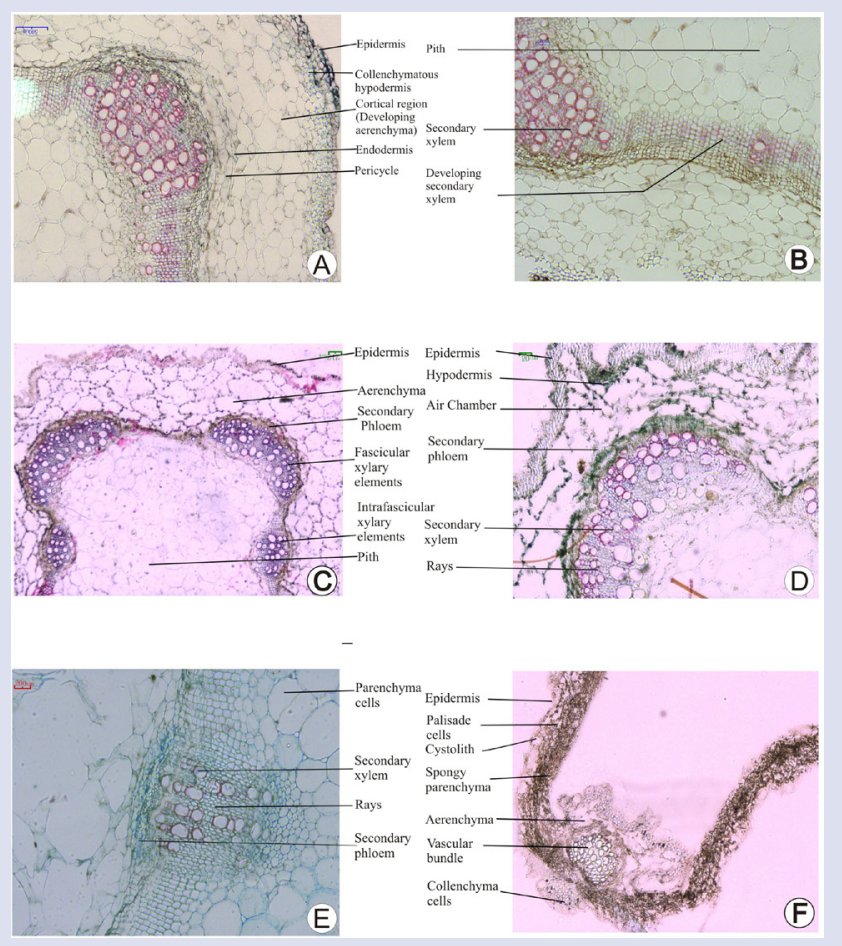

Plate 3: Hygrophila spinosa. A Enlarged view of young stem through region showing developed vascular bundles; B. Enlarged view of young stem showing developing interfascicular vascular bundles; $C$. Transverse section of mature stem section showing well developed arenchyma; D. Enlarged view of mature stem through angular region showing the fully developed secondary xylem and phloem; E. Transverse section of mature stem through interfascicular region showing fully developed vascular bundles; F. Transverse section of leaf lamina through midrib region showing planoconvex midrib and collenchyma cells on dorsal side.
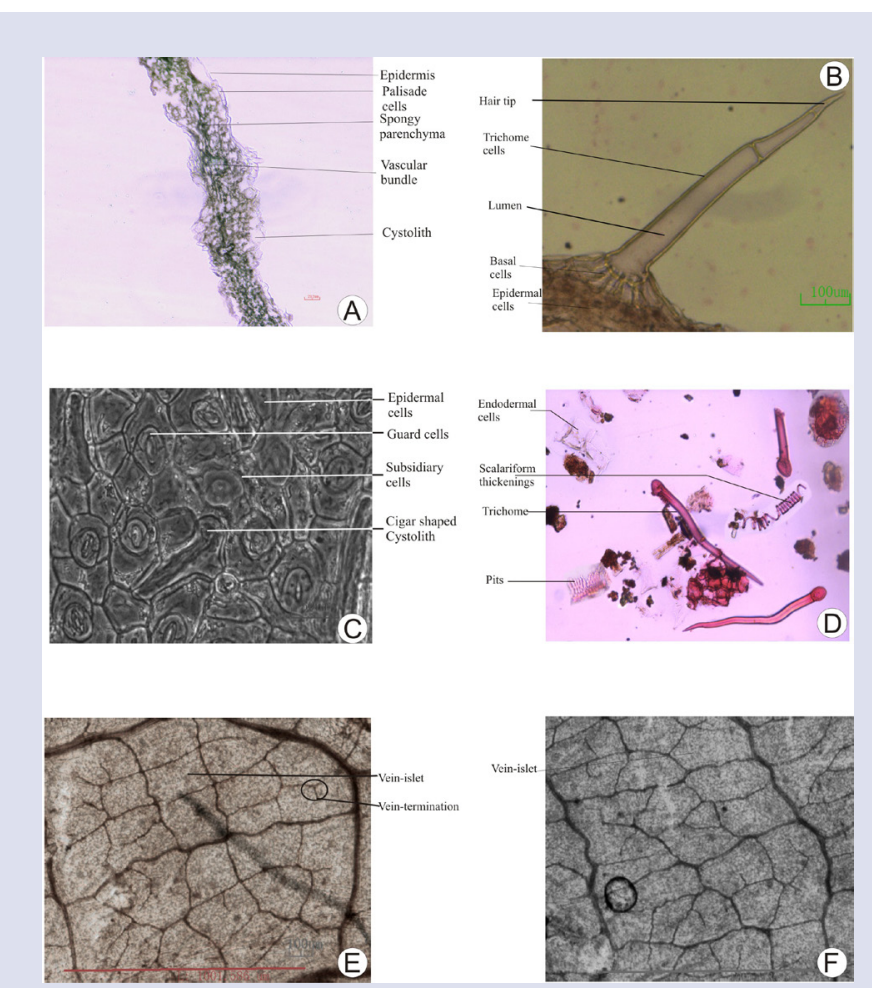

Plate 4: Hygrophila spinosa. A. Transverse section of leaf blade showing epidermis, palisade layer, spongy layer and small vascular bundles; B. Enlarged view of uniseriate multicellular hair present on the surface of leaf; C. Leaf peel showing the distribution of stomata and epidermal cells on the leaf surface; D. Powdered microscopy showing the fragment of epidermal cells, scalariform thickening, trichomes and parenchymatous pith cells; E \& F. Leaf peel showing the vein-islet and vein termination in different region of leaf after treatment with chloral hydrate. followed by single layered pericycle and four semicircular, thicker vascular bundles present at each corner of margin. New small developing vascular bundles present in between two mature vascular bundles; hence one developing vascular bundle was present between each developed vascular bundle. Pith broad with irregular compact parenchymatous cells without intercellular spaces. No cellular inclusion is seen in any region (Plate $2 \mathrm{E}$ and $\mathrm{F}$; Plate $3 \mathrm{~A}$ and $\mathrm{B}$ ).

Mature stem: Transection of mature stem showed almost similar morphology to young stem except for irregular semi-quadrangular outline, well developed large, irregular, elongated net of cells forming broad aerenchymatous cortical region and well developed four secondary vascular bundles and two vascular bundles opposite to each other; epidermal cells were barrel-shaped followed by prominent collenchymatous hypodermis. Cortex was aerenchymatous formed due to long cylindrical to angular thin-walled parenchymatous cells. Endodermis and pericycle prominent followed by well-developed cambial ring formed due to activities of fascicular and intrafasicular cambium. Cambial ring active and functional normally only in vascular bundles region where as it showed abnormal division in an inter-fascicular region where it forms only uniseriately arranged thin-walled parenchymatous cells in inner side. Secondary phloem and secondary xylem developed where xylem vessels lignified and broad, tracheary elements prominent with spiral and annular thickenings present, tracheids showed simple pits; rays multiseriate; pith broad and parenchymatous cells started degenerating resulted into hollow pith; no cellular inclusion is seen in any region (Plate $3 \mathrm{C}, \mathrm{D}$ and E).

Leaf: Leaf morphology showed smooth surfaced isobilateral leaf having planoconvex prominent midrib. Leaf peeling shows almost similar morphology on both sides having polygonal angular epidermal cells and anomocytic stomata surrounded by $2-3$ subsidiary cells. Few cigar shaped cystolith having calcium carbonate crystals were present on the surfaces. Hairs were two types 1 . Non-glandular unicellular hairs with pointed end and 2. Non-glandular uniseriate multicellular hairs. Transaction of leaf showed single layered papillose upper and lower epidermis, multicellular glandular trichomes present on both sides, cystolith region clearly visible and below epidermal region 2 - 3 layered collenchymatous cells were present followed by mesophyll which was differentiated into spongy parenchyma and palisade cells; midrib planoconvex and more prominent in lower side than the upper one. In upper midrib region have only collenchymatous cells while in the lower region well-developed meristele was present. Lower midrib region epidermis followed by 2 - 3 layered collenchyma and broad aerenchyma in the lower region was present. Central large, crescent-shaped meristele present having collateral, conjoint and open vascular bundles surrounded by parenchymatous sheath; leaf amphistomatous with anomocytic stomata present (Plate 3 F, Plate 4 A-C). 


\section{Fluorescent Analysis}

Table 1: Fluorescent analysis of powered drug after treatment with different chemicals.

\begin{tabular}{|c|c|c|c|}
\hline \multirow[b]{2}{*}{ Treatment } & \multirow[b]{2}{*}{ Visible light } & \multicolumn{2}{|c|}{ Ultra-violet Light } \\
\hline & & $\begin{array}{l}\text { Short wave } \\
\text { length } \\
(254 \mathrm{~nm})\end{array}$ & $\begin{array}{l}\text { Long wave } \\
\text { length } \\
(365 \mathrm{~nm})\end{array}$ \\
\hline Powder & Light brown & Brown & Brown \\
\hline Powder + Methanol & Light brown & Light brown & Brown \\
\hline Powder + Glacial Acetic acid & Dark brown & Brown & Black \\
\hline $\begin{array}{c}\text { Powder }+10 \% \text { Sodium } \\
\text { Hydroxide }\end{array}$ & Brown & Brown & Brown \\
\hline Powder + dil. Ammonia & Black & Dark brown & Black \\
\hline Powder + conc. Nitric acid & Orange & Light brown & Black \\
\hline Powder $+1 \mathrm{M}$ sulphuric Acid & Brown & Brown & Brown \\
\hline $\begin{array}{c}\text { Powder }+1 \text { M Hydrochloric } \\
\text { Acid }\end{array}$ & Light brown & Light brown & Brown \\
\hline Powder $+10 \%$ Ferric Chloride & Greenish & Brown & Black \\
\hline Powder + Acetone + Methanol & Light brown & Light brown & Brown \\
\hline Powder $+10 \%$ Iodine & Brown & Brown & Black \\
\hline Powder + Picric acid & $\begin{array}{l}\text { Yellowish } \\
\text { brown }\end{array}$ & Light green & Brown \\
\hline Powder + Petroleum Ether & Light brown & Light brown & Brown \\
\hline
\end{tabular}

\section{Powder Analysis}

Organoleptic evaluation: Powdered drug showed light brown colour and rough textured, odour was characteristic and tasteless.

Powder microscopy: Powder drug under light microscope showed fragments of polygonal epidermal cells with anomocytic stomata; few fragments of parenchymatous cells, phloem fibres, tracheary elements with annular and reticulate thickenings, tracheids with pits, uniseriate unicellular and multicellular hairs (Plate $4 \mathrm{D}$ ).

Quantitative microscopy: Leaves of drug shows amphistomatous nature having anomocytic stomata, present on both the surface, except in midrib region and secondary vein region of lower surface. Stomata were unevenly distributed and more prominent in the lower side having stomatal index 38.68 in lower side and 26.21 in upper side, palisade ratio $4-8$, vein islet $19-21$ per $\mathrm{mm}$ square and vein termination 13 per $\mathrm{mm}$ square (Plate $4 \mathrm{C}, \mathrm{E}$ and $\mathrm{F}$ ).

\section{DISCUSSION}

Traditional medicinal system is mainly based on plant source. Therefore the precise identification as well as characterisation is the basic need for further qualitative work. Efficacy of any drug is directly linked with the authenticity of the plant material. Macroscopic, microscopic and fluorescence analysis is very essential tool in less economic country to standardize the raw material which are the base of any drug formulation. Among these tools, microscopy is one of the major techniques for identification of internal structure of any plant material. Although, recently published articles reported some parameters for Hygrophila spinosa but they are insufficient for proper characterization of this plant. ${ }^{4}$ Many studies are present regarding Hygrophila but these studies were mainly focused on Phytochemical analysis. ${ }^{18}$ Therefore there is instant need to elaborate the primary level of identification i.e. proper morpho-anatomical work of the plant and to find out the parameters which may be useful for further standardization purpose of this plant.
The present study illustrated following parameters which have not been reported yet. The stomatal index, palisade ratio, vein islet and vein termination which may become important parameters to evaluate and fix standards of studied raw plant. These standard parameters will helpful to diagnose the plant drug for the quantitative determination of some pharmacognostical parameters that will be further useful for establishing standards of Hygrophila spinosa. Fluorescent analysis revealed that there was little colour change observed at short wave length level, however, there were no changes recorded at long wave length level, therefore, it may be concluded that fluorescent compounds may be present in studied plant (Table 1). These morpho-anatomical characteristics may serve as standard marker and can be included as microscopic standards in any pharmacopoeia. This study will be helpful in future to identify and select the authentic plant of Hygrophila spinosa for further homoeopathic drug preparation.

\section{ACKNOWLEDGEMENT}

The authors are thankful to Ministry of AYUSH and Central Council for Research in Homoeopathy, New Delhi for financial and technical support and cooperation.

\section{CONFLICT OF INTEREST}

The authors declare no conflict of interest.

\section{ABBREVIATIONS}

cm: Centimetres, mm: Millimetres; nm: Nanometres; min: Minutes; dil.: Dilute; conc.: Concentrate; TBA: Tertiary Butyl Alcohol; U.V. light: Ultra violet light; M: Molar.

\section{REFERENCES}

1. Boericke W. Pocket Manual of Homoeopathic Materia Medica and Repertory. $9^{\text {th }}$ ed. New Delhi: Indian Books and Periodicals Syndicate. 1927;1056.

2. Khare CP. Indian medicinal plants: An illustrated dictionary. New Delhi: Springer Publications. 2007;317-18

3. Bera S, Das S, Roy A. Ethnobotanical study of Kulekhara (Hygrophila auriculata)a review. Sasta Mukhpatra Annual Technical Issue. 2017;21:232-4.

4. NigamV, Mishra RK, Gupta A, Bhati MK. Pharmacognostic study characterization of marker compounds and pharmacological review or aerial parts of Hygrophila auriculata (Schumach) Heine. World J Pharm Pharm Sci. 2015;4(12):1127-43.

5. Anonymous. Wealth of India. New Delhi: Publication and Information Directorate CSIR. 1959;5:148.

6. Maheshwari JK. The Flora of Delhi, New Delhi: Publication and Information Directorate, CSIR. 1963;267.

7. Chopra RN, Nayar SL, Chopra IC. Glossary of Indian Medicinal Plants. New Delhi: Publication and Information Directorate, CSIR. 1992;28.

8. Chopra RN, Chopra IC, Handa KL, Kapur LD. Indigenous Drugs of India. 1st ed. Calcutta: UN Dhur and Sons Pvt. Ltd. 1933;353,603,665,693.

9. Nadkarni AK. Indian Materia Medica. In: Nadkarni KM, Editor. Bombay: Bombay Popular Prakashan. 1976;1:667-9.

10. Nikam D, Mundada S, Mishra D. Kokilaksha: A Potential Ayurvedic Herb. Int J Res Ayur Pharm. 2012;3(6):780-2.

11. Kshirsagar AD, Ingale KG, Vyawahare NS, Thorve VS. Hygrophila spinosa: A comprehensive review. Pharmacog Rev. 2010;4(8):167-71.

12. Anonymous. Homoeopathic Pharmacoepia of India. New Delhi: Department of Ayurveda, Yoga and Naturopathy, Unani, Siddha and Homoeopathy. 2006;9:148-9

13. Misra TN, Singh RS, Pandey HS, Singh BK, Pandey RP. Constituents of Asteracantha longifolia. Fitoterapia. 2001;72(2):194-6.

14. Rastogi RP, Mehrotra BN. Compendium of Indian Medicinal Plants. New Delhi: Publication and Information Directorate, CSIR. 1993;3:351.

15. Kirtikar KR, Basu BD. Indian Medicinal Plants. Dehradun: International Book Distributors. 2005;3:1863-5.

16. Johnson AD. Plant Micro technique. New York: McGraw-Hill. 1940;105.

17. Trease GE, Evans WC. Pharmacognosy. Harcourt Brace and Co. 2002;512-47.

18. Salve SD, Bhuktar AS. Pharmacognosy and Phytochemical evaluation of Hygrophila auriculata (Schumach.) Heine Root. J Phytopharm. 2017;6(4):210-6. 


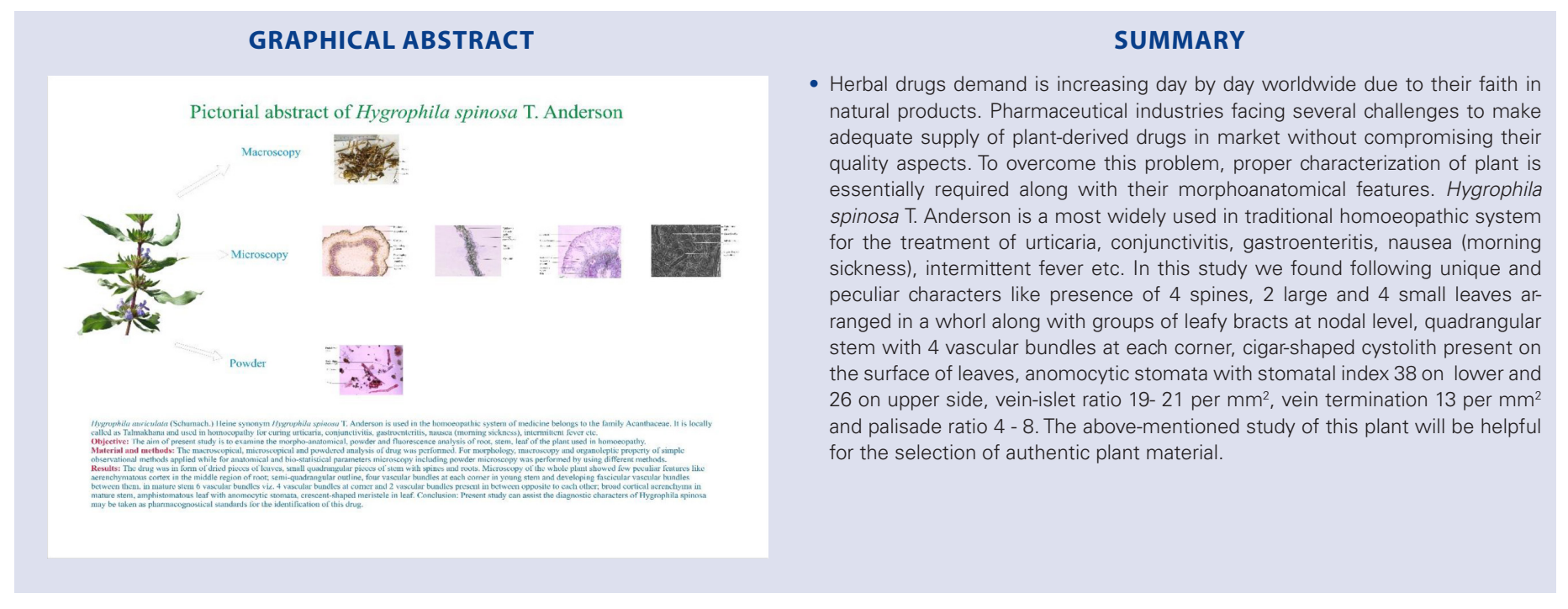

Cite this article: Verma D, Singh S, Arya R, Rajan S, Arya BS, Khurana A, et al. Morpho-anatomical Observations on Homoeopathic Plant Drug Hygrophila spinosaT. Anderson. Pharmacog J. 2019;11(2):286-91. 